\title{
QUEEN'S
UNIVERSITY
BELFAST
}

\section{Development and validation of an ultrasensitive fluorescence planar waveguide biosensor for the detection of paralytic shellfish toxins in marine algae}

Meneely, J. P., Campbell, K., Greef, C., Lochhead, M. J., \& Elliott, C. T. (2013). Development and validation of an ultrasensitive fluorescence planar waveguide biosensor for the detection of paralytic shellfish toxins in marine algae. Biosensors and Bioelectronics, 41(null), 691-697. https://doi.org/10.1016/j.bios.2012.09.043

\section{Published in:}

Biosensors and Bioelectronics

\section{Document Version:}

Peer reviewed version

Queen's University Belfast - Research Portal:

Link to publication record in Queen's University Belfast Research Portal

\begin{abstract}
Publisher rights
This is the author's version of a work that was accepted for publication in Biosensors and Bioelectronics. Changes resulting from the publishing process, such as peer review, editing, corrections, structural formatting, and other quality control mechanisms may not be reflected in this document. Changes may have been made to this work since it was submitted for publication. A definitive version was subsequently published in Biosensors and Bioelectronics, VOL 41, 03/2013
\end{abstract}

\section{General rights}

Copyright for the publications made accessible via the Queen's University Belfast Research Portal is retained by the author(s) and / or other copyright owners and it is a condition of accessing these publications that users recognise and abide by the legal requirements associated with these rights.

Take down policy

The Research Portal is Queen's institutional repository that provides access to Queen's research output. Every effort has been made to ensure that content in the Research Portal does not infringe any person's rights, or applicable UK laws. If you discover content in the

Research Portal that you believe breaches copyright or violates any law, please contact openaccess@qub.ac.uk. 


\section{Author's Accepted Manuscript}

Development and validation of an ultrasensitive fluorescence planar waveguide biosensor for the detection of paralytic shellfish toxins in marine algae

Julie P. Meneely, Katrina Campbell, Charles Greef, Michael J Lochhead, Christopher T Elliott

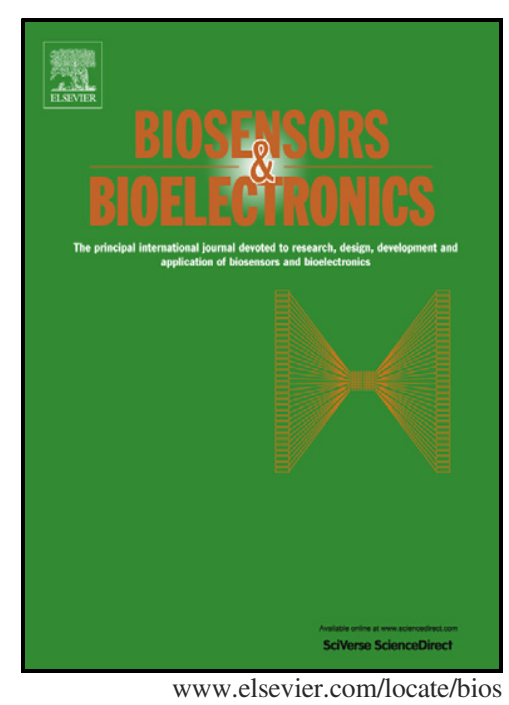

PII:

S0956-5663(12)00649-5

DOI: http://dx.doi.org/10.1016/j.bios.2012.09.043

Reference:

BIOS5439

To appear in: Biosensors and Bioelectronics

Received date: 31 July 2012

Revised date: 12 September 2012

Accepted date: 22 September 2012

Cite this article as: Julie P. Meneely, Katrina Campbell, Charles Greef, Michael J Lochhead and Christopher T Elliott, Development and validation of an ultrasensitive fluorescence planar waveguide biosensor for the detection of paralytic shellfish toxins in marine algae, Biosensors and Bioelectronics, http://dx.doi.org/10.1016/ j.bios.2012.09.043

This is a PDF file of an unedited manuscript that has been accepted for publication. As a service to our customers we are providing this early version of the manuscript. The manuscript will undergo copyediting, typesetting, and review of the resulting galley proof before it is published in its final citable form. Please note that during the production process errors may be discovered which could affect the content, and all legal disclaimers that apply to the journal pertain. 


\section{Development and validation of an ultrasensitive fluorescence planar waveguide biosensor for the detection of paralytic shellfish toxins in marine algae}

Julie P. Meneely ${ }^{a^{*}}$, Katrina Campbell ${ }^{a}$, Charles Greef ${ }^{b}$, Michael J Lochhead $^{b}$, Christopher T Elliott ${ }^{a}$ anstitute of Agri-food and Land Use, School of Biological Sciences, Queen's University, Malone Road, Belfast, BT9 5BN, United Kingdom

${ }^{b}$ MBio Diagnostics Inc, Boulder, Colorado, 80301, USA

*Corresponding author at: Institute of Agri-food and Land Use, School of Biological Sciences, Queen's University, Malone Road, Belfast, BT9 5BN, United Kingdom

Tel: +44 (0) 2890976562

Fax: $+44(0) 2890976513$

Email address: j.p.meneely@qub.ac.uk

\section{ABSTRACT}

Marine dinoflagellates of the genera Alexandrium are well known producers of the potent neurotoxic paralytic shellfish toxins that can enter the food web and ultimately present a serious risk to public health in addition to causing huge economic losses. Direct coastal monitoring of Alexandrium spp. can provide early warning of potential shellfish contamination and risks to consumers and so a rapid, sensitive, portable and easy-to-use assay has been developed for this purpose using an innovative planar waveguide device.

The disposable planar waveguide is comprised of a transparent substrate onto which an array of toxinprotein conjugates is deposited, assembled in a cartridge allowing the introduction of sample, and detection reagents. The competitive assay format uses a high affinity antibody to paralytic shellfish 
toxins with a detection signal generated via a fluorescently labelled secondary antibody. The waveguide cartridge is analysed by a simple reader device and results are displayed on a laptop computer. Assay speed has been optimised to enable measurement within $15 \mathrm{~min}$. A rapid, portable sample preparation technique was developed for Alexandrium spp. in seawater to ensure analysis was completed within a short period of time. The assay was validated and the LOD and CC $\beta$ were determined as $12 \mathrm{pg} / \mathrm{mL}$ and $20 \mathrm{pg} / \mathrm{mL}$ respectively with an intra-assay $\mathrm{CV}$ of $11.3 \%$ at the $C C \beta$ and an average recovery of $106 \%$. The highly innovative assay was proven to accurately detect toxin presence in algae sampled from the US and European waters at an unprecedented cell density of 10cells/L.

Keywords: Paralytic shellfish toxins, fluorescence immunoassay, planar waveguide, Alexandrium spp, early warning, ultra sensitive.

\section{Introduction}

Phytoplankton is intrinsic to the marine ecosystem as they produce a significant proportion of the photosynthetic biomass that zooplankton and larger life forms rely on. Under specific conditions of high nutrient levels from agricultural, domestic and industrial discharges, these microalgae proliferate and produce harmful algal blooms (HABs, also known as "red tides") (James et al., 2010). Various HAB species are toxic and can lead to poisoning of humans, fish and other wildlife via food web transfer (Batoréu et al., 2005). While many dinoflagellate genera cause HABs, one of the most important is the Alexandrium genus because of its global distribution, diversity and severity of the toxins produced (Churro et al., 2010). This genus is responsible for the production of saxitoxins (STX) that cause paralytic shellfish poisons (PSPs) throughout the world (Anderson et al., 2012).

PSP in humans is caused by the consumption of contaminated bivalves and other shellfish that have accumulated STX during filter feeding. The STX are potent neurotoxins that bind to the sodium channels 
in nerve cell membranes disrupting normal depolarization. To date 57 STX analogues have been identified and are collectively referred to as paralytic shellfish toxins (PSTs) (Wiese et al., 2010), all exhibiting different toxicities.

Coastal monitoring for the presence and identification of marine toxic algae and the concentrations of PSTs produced is a significant challenge (Anderson, 2009). That said while monitoring is clearly required, the costs must be controlled. As a result, field deployable, sensitive, rapid qualitative tests will help provide protection of these areas.

Many methods of analysis exist for the measurement of the PSTs but generally these assays are designed for shellfish. In the absence of any regulations for PST concentrations in coastal waters, these techniques may not have the necessary sensitivity to provide early warning of these toxins. The reference method of analysis for shellfish is the mouse bioassay (MBA) (AOAC Official Method 959.08, 2005) however it is not sensitive enough as an early warning detection of PSTs in coastal waters. In addition to its technical shortcomings for water analysis, ethical considerations are becoming more important globally (Campbell et al., 2011a). The AOAC HPLC method (AOAC Official Method 2005.06., 2005) has found acceptance for screening, however sample preparation is lengthy and the interpretation of the results extremely complex requiring highly trained personnel (van den Top et al., 2011). Another HPLC method frequently used is that developed by Oshima (1995) however three different analyses are required to identify the PST derivatives. In recent times LC-MS/MS has emerged as a powerful tool for the analysis of PSTs (Jaime et al., 2001 and Dell'Aversano et al., 2005). While these methods allow for the accurate determination of these toxins in phytoplankton, they are laboratory based requiring skilled technicians and expensive equipment. More rapid immunological based methods have emerged over the past decade. One such example is biosensor assays based on surface plasmon resonance (Fonfria et al., 2007; Rawn et al., 2009; Campbell et al., 2010 and Haughey et 
al., 2011), however again these have been designed for determination of the toxins in shellfish, are laboratory based and require a large capital outlay.

Many ELISAs have seen applied to the detection of PSTs in shellfish samples but few have been tested for phytoplankton. They are specifically designed for screening, but are not truly portable requiring a reader. Often the sensitivity is high, but inaccurate results may occur as a result of the antibody specificity (Usleber et al., 2001; Dubois et al., 2010). One approach to alleviate the problem of underestimation of results is to combine two antibodies into the test format as described by Campbell et al (2011b) or employ two assays (Chu et al, 1996). Several commercial ELISA kits exist for the screening of PSTs, however only one has been applied to the determination of STX in water samples, the Abraxis Saxitoxin (PSP) ELISA kit. An alternative immunological format is that of Lateral Flow Devices (LFDs) which are designed to be used in field conditions and give a qualitative result, but again they have only been tested in shellfish.

A receptor binding assay (Doucette et al, 1997) and cytotoxicity/cell culture methods have been developed (Garthwaite, 2000) however while useful for research they may be very difficult to introduce for monitoring purposes. Field deployable techniques such as a neuronal network biosensor (Kulagina et al., 2006) and the use of synthetic resins to adsorb PSTs (Rodríguez et al, 2011) have been published. This study investigated the use of fluorescence immunoassay planar waveguide as an early warning detection system for PSTs produced by the Alexandrium spp. The assay has been shown to be rapid, easy-to-use and is ultra sensitive allowing detection of these toxins at very low algal cell densities. It can be applied in the field and thus raises the possibility of providing, for the first time, a fit-for-purpose monitoring tool for coastal regions often affected by HABs.

\section{Materials and methods}

\subsection{Apparatus}


A Minimix standard shaker was purchased from Merris Engineering, Maidenhead, UK. The SnapEsi ${ }^{\circ}$ LS System and microarray cartridges were supplied by MBio Diagnostics Inc. (Boulder, USA). BagPage ${ }^{\circledR}+80$ (full surface micro-perforated filter blender bags, filter $280 \mu \mathrm{m}$ ) were supplied by Interscience, France.

\subsection{Reagents}

All chemicals were of Analar grade unless otherwise stated. Phosphate buffered saline (PBS) tablets, Tween 20, bovine serum albumin (BSA), dimethylsulphoxide, boric acid, tris (hydroxymethyl) aminomethane, 2,2'-(ethylenedioxy)bis(ethylamine) (jeffamine, MW 148.2) and HPLC grade water and acetonitrile were purchased from Sigma-Aldrich, United Kingdom.

Polyclonal antibodies against saxitoxin (QUB 5) and neosaxitoxin (QUB 7), (1mg/mL) and toxin protein conjugates, saxitoxin-ovalbumin and neosaxitoxin-ovalbumin $(1 \mathrm{mg} / \mathrm{mL})$ were prepared in-house. Alexa Fluor $^{\circledast} 647$ goat anti-rabbit lgG, $(2 \mathrm{mg} / \mathrm{mL})$ and Alexa Fluor ${ }^{\circledast} 647$ carboxylic acid, succinimidyl ester, (1mg), were purchased from Invitrogen Ltd, Paisley, Scotland.

PST standards saxitoxin (STX), decarbamoyl saxitoxin (dcSTX), neosaxitoxin (NEO), decarbamoyl neosaxitoxin (dcNEO), gonyautoxins (GTX1/4 and GTX 2/3), decarbamoyl gonyautoxins (dcGTX 2/3), GTX5 (B1) and C1/2 standard solutions were obtained from the National Research Council of Canada, (NRC), Halifax, Canada. All standards were diluted in PBS ( $\mathrm{pH} 7.2$ ) to prepare working standards for the immunoassay and HPLC analysis. For the preparation of the toxin protein conjugates, STX and NEO were also purchased from the NRC.

Strains of Alexandrium tamarense (Lebour) Balech, CCAP 1119/20, 1119/27 and 1119/32 were purchased from the Culture Collection of Algae and Protozoa, Scottish Marine Institute, Oban, Scotland (CCAP). Two further strains, Alexandrium fundyense (Lebour) Balech, F14 and GTCA28 were supplied by the School of Marine Sciences, University of Maine, USA. L1 medium for marine dinoflagellates was 
purchased from the CCAP. Fresh natural seawater was obtained from Strangford Lough, Co. Down, Northern Ireland.

\subsection{The assay cartridge and instrument}

Assays were performed using the SnapEsi ${ }^{\circledR}$ LS System from MBio Diagnostics Inc. The SnapEsi System is a multiplexed, fluorescence immunoassay platform in development for clinical diagnostics and life sciences applications. It combines single-use disposable cartridges with a simple reader, and is described in detail elsewhere (Lochhead et al., 2011 ). The system utilizes a novel implementation of planar waveguide technology. Planar waveguides for immunoassays have been the subject of several technical reviews (Herron et al., 2005; Ligler., 2009; Mukundan et al., 2009). Briefly, a light source (typically a laser) is directed into a waveguide substrate where it propagates by total internal reflection (TIR) at the interface between the high index of refraction waveguide (glass or plastic) and the surrounding medium (air or aqueous solution). At the TIR interface, an evanescent field is generated that decays exponentially into the aqueous medium. This provides localized illumination of the assay surface, minimising effects of the bulk solution, line-of-sight, light scattering, etc.

The key innovation of the MBio Diagnostics planar waveguide system is an optical design that provides an easy-to-use, reproducible, all plastic disposable cartridge that avoids the cost and alignment issues that have limited adoption of planar waveguide technology in high volume applications.

\subsection{Microarray construction}

Toxin-protein conjugates were printed to chemically activated waveguides (Grainger et al., 2007) at defined concentrations as depicted in Figure 1. Fluorescently labelled protein conjugate was printed as a spatial orientation marker, and anti-species antibodies served as procedural controls. Arrays were printed with a Bio-Dot AD3200 robotic arrayer equipped with a Bio-Jet print head dispensing $20 \mathrm{~nL}$ 
droplets. Spot diameters were approximately $0.5 \mathrm{~mm}$ and the arrays were printed on a grid with $1 \mathrm{~mm}$ centres. For the final array, each toxin-protein conjugate was printed in replicates of four. After printing, the waveguide arrays were rinsed with a protein-based blocking agent and dried by centrifugation.

Printed waveguides were assembled into an injection moulded cartridge using die cut double sided adhesive, forming a $5 \mathrm{~mm}$ wide fluidic channel with a volume of approximately $30 \mu \mathrm{L}$. The cartridge inlet port provides a reservoir for introduction of assay fluids. All assay fluids stay on-board the cartridge (minimizing biohazard), with total waste volume up to $1 \mathrm{~mL}$ irreversibly trapped in an absorbent pad. The cartridge has been engineered to provide reproducible, passive fluid flow, driven by a combination of capillary action and hydrostatic pressure.

\subsection{Toxin protein conjugates}

STX was conjugated to the carrier protein, keyhole limpet haemocyanin (KLH) via a modification of the Mannich reaction incorporating jeffamine as a spacer compound and polyclonal antibodies (PAb) were prepared in a similar manner to that reported previously for bovine serum albumin (Campbell et al., 2007). The antibody was purified by ammonium sulphate precipitation followed by dialysis in $0.15 \mathrm{M}$ saline and the protein concentration was determined by $A_{280}$ to be $8.3 \mathrm{mg} / \mathrm{mL}$. For the microarray, neosaxitoxin was conjugated to the carrier protein ovalbumin using the same conjugation chemistry as above in the following ratios but omitting the jeffamine linker. Ovalbumin (1mg), neosaxitoxin $(146 \mu \mathrm{g})$ and formaldehyde $(4.5 \mu \mathrm{L})$ were reacted followed by dialysis over $24 \mathrm{~h}$ in $3 \mathrm{x}$ $4 \mathrm{~L}$ of $0.15 \mathrm{M}$ saline solution.

2.6. Labelling the primary antibody with Alexa Fluor ${ }^{\circledR} 647$ carboxylic acid, succinimidyl ester 
In brief, $50 \mu \mathrm{g}$ of the saxitoxin antibody was placed in an Amicon UltraCel 30K membrane centrifugal filter and $100 \mu \mathrm{L} 50 \mathrm{mM}$ borate buffer, $\mathrm{pH} 8.0$ added. This was centrifuged twice at $13,400 \times \mathrm{g}$ for $10 \mathrm{~min}$, the protein solution removed and Alexa Fluor ${ }^{\circledR} 647$ carboxylic acid, succinimidyl ester added (20-30 equivalents of dye to protein). These were mixed vigorously for $2 \mathrm{~h}$ at room temperature, shielded from direct sunlight. The reaction was quenched by the addition of an equal volume of $0.1 \mathrm{M}$ tris buffer, $\mathrm{pH}$ 8.5 and the contents transferred to another centrifugal filter. The volume was made up to $400 \mu \mathrm{L}$ with PBS containing $0.05 \%$ Tween 20 and centrifuged at 13,400 x g for $10 \mathrm{~min}$. The supernatant was discarded and $400 \mu \mathrm{L}$ of the above buffer added and centrifuged as before. This process was repeated 3 times until the supernatant was colourless. The labelled antibody was stored at $-20^{\circ} \mathrm{C}$ until use.

\subsection{Antibody specificity}

Antibody cross-reactivity was determined in assay buffer (PBS, pH 7.2, 1\% BSA, 0.05\% w/v Tween 20) spiked with structurally related analytes. The calibration points were $0,0.02,0.04,0.08$ and $1.6 \mathrm{ng} / \mathrm{mL}$. The fluorescence signal obtained for each calibration point $(n=4)$ was normalized by calculating the percentage of bound antibody for each, relative to the zero calibration signal observed. The mean values were plotted using the non-linear four parameter equation using BIA evaluation software. The midpoint concentration $\left(\mathrm{IC}_{50}\right)$ of each toxin curve was determined and the cross-reactivity calculated as a percentage relative to STX.

\subsection{Immunoassay procedure}

The microarray cartridge was pre-conditioned with assay buffer $(150 \mu \mathrm{L})$ for $10 \mathrm{~min}$. Antibody $(100 \mu \mathrm{L})$ and STX standard/sample $(100 \mu \mathrm{L})$ were mixed together and $150 \mu \mathrm{L}$ applied to the cartridge for $15 \mathrm{~min}$ 
followed by two sample rinses using assay buffer $(2 \times 150 \mu \mathrm{L}$ ). The labelled antibody (Alexa Fluor 647 goat anti-rabbit IgG at a concentration of $10 \mu \mathrm{g} / \mathrm{mL}$; in assay buffer) was applied to the cartridge and incubated for $10 \mathrm{~min}$. Two label rinse steps were performed as before and the data recorded on the SnapEsi ${ }^{\circ}$ System. This assay procedure required $45 \mathrm{~min}$ to complete. Optimal working dilutions of antibodies and toxin-protein conjugates were determined experimentally by the checkerboard titration method using this protocol.

\subsection{Algal culturing}

L1 medium was prepared according to the manufacturer's guidelines in filtered seawater.

All glassware and media were sterilized prior to use and subsequent protocols performed in a UV3 HEPA PCR cabinet. The cultures were grown at $20^{\circ} \mathrm{C} \pm$ ( $5^{\circ} \mathrm{C}$ ) with a $12: 12$ hour light: dark cycle with a photon flux density of approximately $170 \mu \mathrm{mol} / \mathrm{m}^{2} / \mathrm{s}$ in

L1 medium. Batch cultures of each strain were inoculated from a stock culture that had reached the late exponential/early stationary phase and the cultures maintained in duplicate under the conditions described above.

\subsection{Algal cell lysis and extraction of PSTs}

Chemical and mechanical methods were investigated. Briefly, $10 / 15 \mathrm{~mL}$ of culture was filtered using Millipore hydrophilic mixed cellulose esters filters $(0.45 \mu \mathrm{m})$. The algal cells were washed off the filter prior to reconstitution in $0.9 / 1.5 \mathrm{~mL}$ of PBS. For chemical lysis $100 \mu \mathrm{L}$ copper sulphate/Lysozyme was added to the algal cells for $10 \mathrm{~min}$. Mechanical lysis employed a metal seam roller to crush the cells in sample bags for $1.5 \mathrm{~min}$. Concentrated cultures were also placed into tubes and whisked for 2 min with a hand blender. Cell counts were performed prior to and after each treatment as follows. Triplicate $1 \mathrm{~mL}$ volumes of each culture were collected and fixed with Lugol's iodine solution. $1 \mathrm{~mL}$ was transferred 
to a Sedgewick-Rafter counting chamber for enumeration. Cell counts were performed manually at $x$ 100 magnification on an inverted light microscope.

The 'gold' standard mechanical lysis method used was based on a modified version of glass bead beating described by Devlin et al (2011). Briefly $10 \mathrm{~mL}$ of culture was concentrated by centrifugation, the supernatant discarded and the cells re-suspended in PBS. Glass beads were added and the samples placed in a Minimix standard shaker for $10 \mathrm{~min}$. Cell enumeration was performed prior to extraction to enable the determination of total PST per cell in addition to the culture toxin profiles. Extracts from this method and the most efficient portable method were analysed by HPLC.

\subsection{HPLC analysis of algal extracts}

All extracts were analyzed to characterize the toxin profiles and quantify the toxin concentrations in each. The PSP toxin concentrations from the standard and portable lysis method selected were compared. The official AOAC method was used (AOAC Official Method 2005.06., 2005).

\subsection{Assay performance}

Limit of detection (LOD) for the assay was determined by the analysis of a non-toxic strain of Alexandrium tamarense (Lebour) Balech, CCAP 1119/20 $(n=20)$ and calculated as the mean of the measured fluorescence signal minus 3 times the standard deviation of the mean (mean - 3sd). The detection capability $C C \beta$ was evaluated by fortification of the non-toxic strain at the concentration $20 \mathrm{pg} / \mathrm{mL}$ and analyzed according to the assay protocol. The final assay calibration curve was $0,0.02$, 0.04 and $0.08 \mathrm{ng} / \mathrm{mL}$ prepared by spiking an extract of the non-toxin producing strain at a cell density of 50 cells/L. To determine the sensitivity of the assay with respect to cell numbers, both non-toxic and 
toxic strains of Alexandrium were subjected to analysis at 50,10 and 5cells/L ( $n=6$ for each strain). Cell counts were performed for each followed by dilutions to the required densities prior to analysis.

\section{Results and discussion}

The competitive assay format uses a high affinity antibody to paralytic shellfish toxins with a detection signal generated via a fluorescently labelled secondary antibody.

The developed assay was designed to provide early warning of PSTs in coastal waters and provides rapid, qualitative results. As such, the sensitivity, specificity, LOD and CC $\beta$ were evaluated to ensure the method was fit-for-purpose. The reproducibility of the printed waveguides was ascertained by performing both buffer and matrix curves over a number of days and using different print batches (see the supporting information section SI1). The standard deviations associated with these were all less than 5 with CV values ranging from $8 \%$ to $68 \%$ ( 25 and $250 \mathrm{pg} / \mathrm{mL}$ ) for buffer ( 2 batches) (Table SI1). For the matrix curves ( 3 batches) the standard deviations were less than 6 and the CV values ranged from $0.6 \%$ to $56 \%$ (20 and $80 \mathrm{pg} / \mathrm{mL}$ ) (Table $\mathrm{SI} 2$ ). The $\mathrm{IC}_{50}$ values for the calibration curves were consistent at $24 \mathrm{pg} / \mathrm{mL}$. The buffer and matrix curve overlays have been shown in the supplementary section (Figures SI1 and SI2).

The checkerboard titration method highlighted the QUB 5 polyclonal antibody (at a dilution of 1/8,000) provided the most sensitive results with the NEO-ovalbumin conjugate $(50 \mu \mathrm{g} / \mathrm{mL})$. Under buffer conditions an $\mathrm{IC}_{50}$, the concentration of toxin required to cause $50 \%$ inhibition of the antibody binding, of $24 \mathrm{pg} / \mathrm{mL}$ was demonsrated.

One of the main aims during the assay development was to achieve a short assay time. Initially the assay procedure was $45 \mathrm{~min}$ and considered too lengthy for a rapid test. To accomplish a faster analysis time, all washes were removed and the incubation times reduced to $7.5 \mathrm{~min}$ each for the 
antibody/sample followed by the detection antibody. The $\mathrm{IC}_{50}$ was determined as $25 \mathrm{pg} / \mathrm{mL}$ indicating no adverse effects yet a marked improvement in assay time was gained.

Further studies were performed to ascertain if a one-step protocol was possible. Two approaches were investigated, the first mixing the antibody, sample and secondary antibody together and incubating for 15 min prior to reading the data and the second was labelling the primary antibody with the fluorescent tag and applying the sample/antibody mixture for $15 \mathrm{~min}$ prior to reading. The first approach failed as very little binding was exhibited and the second, while it proved more successful showed a significant drop in sensitivity with the $\mathrm{IC}_{50}$ being calculated as $190 \mathrm{pg} / \mathrm{mL}$.

The antibody specificity was evaluated in assay buffer and the cross-reactivities were calculated as $100 \%, 25 \%, 28 \%, 8 \%, 49 \%,<0.1 \%, 7 \%, 33 \%$ and $4 \%$ for STX, C1/2, dcGTX2/3, dcNEO, dcSTX, GTX1/4, GTX2/3, GTX5 and NEO respectively. The antibody was very specific for STX. Some cross-reactivity was exhibited towards dcSTX with less specificity towards dcGTX2,3 and dcNEO but this was not of particular relevance since decarbamoyl toxins are not commonly found in toxic dinoflagellates (Etheridge., 2010). Of significance was the low cross-reactivity of the antibody with the more potent STX analogues NEO and GTX1/4 and if present in the sample then ultimately the test could underestimate the results. These results are fairly consistent with other immunoassay publications (Usleber et al., 2001 and Dubois et al., 2010) however by use of a "cocktail" of antibodies, as described by Campbell et al (2011b) or two immunoassays (Chu et al., 1996), these difficulties may be overcome. Alternatively, the multiplexed nature of the microarray format could allow multiple separate tests to be run, enabling a comprehensive toxin profile assay.

An innovative approach was taken to develop a simple, rapid sample preparation technique compatible with the immunoassay. Importantly one of the necessary requirements of this assay was that it would be field deployable. The study was conducted using 3 cultures of Alexandrium tamarense including F14, GTCA28 and CCAP 1119/20. Chemical and mechanical lysis techniques were trialled as described and 
the most efficient method chosen was initially based on cell counts and percentage lysis rates. Careful selection of the extraction buffer was fundamental, not only to ensure efficient extraction of the toxins but also to avoid any interference with the immunological processes. Instead of using acetic acid or hydrochloric acid as described by Ravn et al (1995), the authors opted for PBS, pH 7.2 (Devlin et al, 2011) to avoid adverse affects on the immunoassay. The results (Fig. 2) demonstrated the chemical lysis techniques investigated were not suitable with lysis rates of $\leq 54 \%$. Physical disruption of the cell wall proved to be successful following crushing of the phytoplankton contained in the BagPage ${ }^{\circledR}+80$ sample bag. A lysis rate of $99.6 \pm 0.2 \%$ was calculated for this method. Removal of the membrane from this system yielded an $83 \pm 7.4 \%$ lysis rate while using a general laboratory sample bag or the hand blender provided lysis rates of only $54 \pm 2.8 \%$ and $18 \pm 8.7 \%$ respectively. Therefore the BagPage ${ }^{\circledR}+80$ and roller were selected. For analysis a filtration step was included after lysis to remove cell debris. The results observed using the new protocol were compared against the modified bead beating method (Devlin et al, 2011), by determining cell counts before and after lysis. Results using the modified bead beating method showed $100 \%$ lysis for all three cultures while $99 \pm 0.3 \%, 99 \pm 0.1 \%$ and $98 \pm 0.2 \%$ lysis was observed for cultures CCAP 1119/20, GTCA28 and F14 respectively using the BagPage ${ }^{\circledR}+80$ and roller. This indicated that the rapid portable method was highly satisfactory. Further investigations to compare the toxin concentrations using both the laboratory-based and portable methods were completed prior to validation of the method to confirm agreement. This was performed by repeating the tests as described and measuring the toxin concentrations by HPLC.

Table 1 highlights the results obtained from this trial. The total concentration of PSTs calculated using the bead beating method was taken as $100 \%$ and those calculated using the portable sample preparation method were measured against this as a reference. The recovery for the Alexandrium strains ranged from $71 \%$ to $91 \%$, a highly acceptable result. In addition the total toxin concentrations 
per cell were calculated for each algal strain, the highest level being produced by Alexandrium fundyense (F14) at the concentration $14.4 \mathrm{pg} / \mathrm{cell}$.

The LOD of the assay was determined as described and a value of $12 \mathrm{pg} / \mathrm{mL}$ was calculated. The lowest concentration of STX (CC $\beta$ ) that could be accurately detected was assessed by fortifying blank samples at $20 \mathrm{pg} / \mathrm{mL}$ and the results presented in Fig. 3. The mean fluorescence signals for each sample were divided by the signal generated by the zero standard and multiplied by 100 . The average normalized fluorescence signal \pm 2 sd were calculated for each population. No overlap was observed between them, the lower limit exhibited for the blank population was $80 \%$ while the upper limit for the spiked population was $68 \%$. The Student's T Test was applied to the two sets of data and the p-value calculated as $3.9 \times 10^{-19}$, confirming the populations were significantly different. The intra-assay variation and extraction recovery were determined by the analysis of the samples spiked at $20 \mathrm{pg} / \mathrm{mL}$. The coefficient of variation (\% CV) was calculated as $11.3 \%$ and the recovery rates ranged from $86 \%$ $123 \%$. Analysis of the Alexandrium strains at various cell densities allowed assessment of assay sensitivity. No guidelines exist for the measurement of toxin in algal cells however shellfish may begin to show signs of toxicity at about 100 cells/L, and above 1000 cells/L the toxin level in mussels may be above the regulatory limit (Blasco et al., 2003). Therefore, the ability to detect toxin in 50cells/L would allow significant early warning for potential contamination of shellfish. To assess if the assay could accurately determine if a sample was positive or negative at a cell density of $50 \mathrm{cell} / \mathrm{S} / \mathrm{L}$, the cultures were diluted, cells lysed and the assay performed $(n=6)$ for each strain and the results are detailed in Table 2. In addition, the performance of the assay was investigated at lower cell densities of $10 \mathrm{cells} / \mathrm{L}$ and 5cells/L. Total toxin concentrations determined by HPLC for the cell densities investigated were found to be greater than 20pg for cultures GTCA28, F14, CCAP 1119/27 and CCAP 1119/32. For CCAP 1119/20 (non-producer), the concentrations were less than 20pg. At 50cells/L and 10cells/L, the assay performance was exceptional, distinguishing between the negative and positive cultures. However at a 
cell density of 5 cells/L, although all the toxin producing algal strains were correctly identified, 2 samples of the non-toxin producing strain gave false positive results. Thus it can be concluded that the assay can perform very satisfactorily at detecting PST production in as low as 10cells/L and at this cell density no false negatives were observed during the validation study. Examining STX only, the assay performed well (Table 3). At 50cells/L there was complete agreement between the HPLC results and those obtained using the portable assay. At 10cells/L, the STX concentrations in the toxin-producing cultures by HPLC were all found to be below 20pg, while the portable assay found these to be positive, i.e. above the cut-off of $20 \mathrm{pg}$. This is not surprising as the portable assay, although highly specific towards STX, will still pick up other toxins present due to the cross-reactivity profile of the antibody. With low levels of $\mathrm{C} 1 / 2, \mathrm{GTX} 2 / 3$, NEO and GTX5 in these algal samples, the portable assay will detect these and display positive results.

\section{Conclusions}

Monitoring of coastal waters for PSTs produced by marine dinoflagellates is of paramount importance to provide an early warning of risk. Rapid, on-site qualitative assays are advantageous in this situation because they are cost-effective and the generation of results is rapid. In this study a rapid, easy-to-use, portable fluorescent planar waveguide immunoassay has been developed and validated to meet these requirements. In conjunction with a novel sample preparation, the total time required to test a sample is approximately 20 minutes. The lowest detectable limit of the assay was in the low $\mathrm{pg} / \mathrm{mL}$ range making it an ultra sensitive method. The assay has been designed to detect toxin levels in Alexandrium spp. known to have global distribution however the method is also likely to be applicable to other PST producing organisms in both the marine and freshwater environments.

\section{Acknowledgements}


The authors thank the Department of Employment and Learning via the All Island Research Programme for funding the Project: BEACONS: Biosafety for EnvironmentAL Contaminants using Novel Sensors (Reference, USI 001). We also thank Dr Laurie Connell and Amber Bratcher of the University of Maine for providing Alexandrium cultures and Dr Gregory Doucette, NOAA/National Ocean Service for his advice during the study.

\section{References}

Anderson, D.M., 2009. Ocean Coast. Manage. 52, 342-347

Anderson, D.M., Alpermann, T.J., Cembella, A.D., Collos, Y., Masseret, E., Montresor, M., 2012. Harmful Algae. 14, 10-35

Batoréu, M.C.C., Dias, E., Pereira, P., Franca, S., 2005. Environ. Toxicol. Pharmacol. 19, 401406

Blasco, D., Levasseur, M., Bonneau, E., Gelinas, R., Packard, T., 2003. Sci. Mar. 67, 261-278

Campbell, K., Haughey, S.A., van den Top, H., van Egmond, H., Vilarino, N., Botana, L.M., Elliott, C.T., 2010. Anal. Chem. 82, 2977-2988

Campbell, K., Rawn, D.F.K., Niedzwiadek, B., Elliott, C.T., 2011b. Food Addit. Contam. A. 28, $711-725$

Campbell, K., Stewart, L.D., Doucette, G.J., Fodey, T.L., Haughey, S.A., Vilarino, N., Kawatsu, K., Elliott, C.T., 2007. Anal. Chem. 79, 5906-5914

Campbell, K., Vilariño, N., Botana, L.M., Elliott, C.T., 2011a. TrAC. 30, 239-253

Chu, F., Hsu, K., Huang, X., Barrett, R., Allison, C., 1996. J. Agric. Food Chem. 44, 4043-4047

Churro C., Alverca, E., Sam-Bento, F., Paulino, S., Figueira, V.C., Bento, A.J., Prabhakar, S., Lobo, A.M., Calado, A.J., Pereira, P., 2010. J. Appl. Phycol. 21, 429-442.

Dell'Aversano, C., Hess, P., Quilliam, M.A., 2005. J. Chromatogr. A. 1081, 190-201 
Devlin, R.A., Campbell, K., Kawatsu, K., Elliott, C.T., 2011. Harmful Algae. 10, 542-548

Doucette, G.J., Logan, M.M., Ramsdell, J.S., Van Dolah, F.M., 1997. Toxicon. 35, 625-636

Dubois, M., Demoulin, L., Charlier, C., Singh, G., Godefroy, S.B., Campbell, K., Elliott, C.T., Delahaut, P., 2010. Food Addit. Contam. A. 27, 859-868

Etheridge, S.M., 2010. Toxicon. 56, 108-122

Fonfria, E.S., Vilarino, N., Campbell, K., Elliott, C., Haughey, S.A., Ben-Gigirey, B., Vieites, J.M., Kawatsu, K., Botana, L.M., 2007. Anal. Chem. 79, 6303-6311

Garthwaite, I., 2000. Trends Food Sci. Technol. 11, 235-244

Grainger, D.W., Greef, C.H., Gong, P., Lochhead, J.L., 2007. Methods Mol Biol. 381, 37-57

Haughey, S.A., Campbell, K., Yakes, B.J., Prezioso, S.M., DeGrasse, S.L., Kawatsu, K., Elliott, C.T., 2011. Talanta. 85, 519-526

Herron, J.N., Wang, H-K., Tan, L., Brown, S.Z., Terry, A.H., Durtschi, J.D., Simon, E.M.,Astill, M.E.,Smith,R.S., Christensen, D.A., 2006. Planar waveguide biosensors for point-of-care clinical and molecular diagnostics in Thompson R.B. (Ed.), Fluorescence sensors and biosensors. Taylor \& Francis CRC Press, Boca Raton, FL, pp. 283-332.

Humpage, A.R., Magalhaes, V.F., Froscio, S.M., 2010. Anal. Bioanal. Chem. 397, 1655-1671

Jaime, E., Hummert, C., Hess, P., Luckas, B., 2001. J. Chromatogr. A. 929, 43-49

James, K.J., Carey, B., O'Halloran, J., van Pelt, F.N.A.M., Skrabakova, Z., 2010. Epidemiol. Infect. $138,927-940$

Kulagina, N., Mikulski, C., Gray, S., Ma, W., Doucette, G., Ramsdell, J., Pancrazio, J., 2006.

Environ. Sci. Technol. 40, 578-583

Ligler, F.S., 2009. Anal. Chem. 81, 519-526 
Lochhead, M.J., Todorof, K., Delaney, M., Ives, J.T., Greef, C., Moll, K., Rowley, K., Vogel, K., Myatt, C., Zhang, X., Logan, C., Benson, C., Reed, S., Schooley, R.T., 2011. J. Clin. Microbiol. $49,3584-3590$

Mukundan, H., Anderson, A.S., Grace, W.K., Grace, K.M., Hartman, N., Martinez, J.S., Swanson, B.I., 2009. Sensors. 9, 5783-5809

Official Methods of Analysis of the Association of Official Analytical Chemists., 2005. $18^{\text {th }}$ ed.; AOAC INT. 88-96

Oshima, Y., 1995. J. AOAC Int. 78, 528-532

Ravn, H., Anthoni, U., Christophersen, C., Nielsen, P., Oshima, Y., 1995. J. Appl. Phycol. 7, $589-594$

Rawn, D.F.K., Niedzwiadek, B., Campbell, K., Higgins, H.C., Elliott, C.T., 2009. J. Agric. Food Chem. 57, 10022-10031

Rodríguez, P., Alfonso, A., Turrell, E., Lacaze, J., Botana, L.M., 2011. Harmful Algae. 10, 447455

Usleber, E., Dietrich, R., Burk, C., Schneider, E., Martlbauer, E., 2001. J. AOAC Int. 84, 16491656

van den Top, H.J., Elliott, C.T., Haughey, S.A., Viarino, N., van Egmond, H.P., Botana, L.M., Campbell, K., 2011. Anal. Chem. 83, 4206-4213

Wiese, M., D'Agostino, P.M., Mihali, T.K., Moffitt, M.C., Neilan, B.A., 2010. Mar. Drugs. 8, 2185-2211 


\section{Figures}

Fig, 1 Schematic of the array layout and representative images of a negative (A) and positive (B) control.

Fig. 2 Bar chart showing the \% lysis rates of Alexandrium spp. cells after both chemical and mechanical treatments.

Fig. 3 Graph detailing the results observed after the analysis of 20 blank samples and 20 samples spiked at $20 \mathrm{pg} / \mathrm{mL}$.

Table 1. Comparative study of the laboratory-based bead beating method and the portable method for lysis of Alexandrium cells.

\section{PSP Toxin Concentration $\mathrm{ng} / \mathrm{ml}$}

$\begin{array}{llllllllll}\text { Alexandrium Lysis } & \text { GTX1/4 } & \text { C1/2 } & \text { NEO } & \text { GTX2/3 } & \text { GTX5 } & \text { STX } & \text { Total } & \% & \text { Total }\end{array}$

Strain Method Recovery toxin

pg /cell

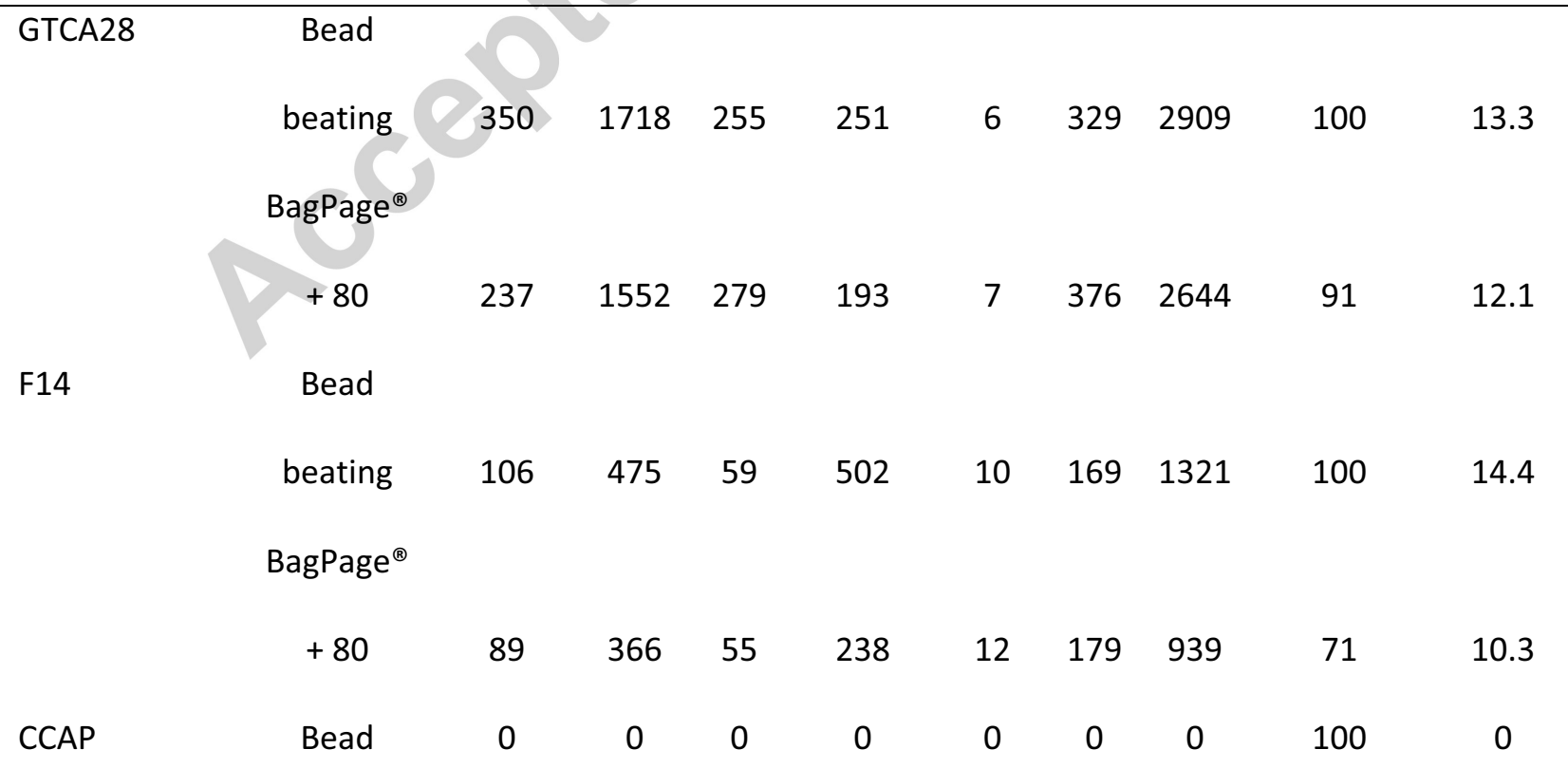




\begin{tabular}{|c|c|c|c|c|c|c|c|c|c|c|}
\hline \multirow[t]{3}{*}{$1119 / 20$} & \multicolumn{10}{|l|}{ beating } \\
\hline & \multicolumn{10}{|l|}{ BagPage $^{\circledR}$} \\
\hline & +80 & 0 & 0 & 0 & 0 & 0 & 0 & 0 & 100 & 0 \\
\hline CCAP & Bead & & & & & & & & & \\
\hline \multirow[t]{3}{*}{$1119 / 27$} & beating & 100 & 796 & 113 & 86 & 6 & 223 & 1324 & 100 & 9.7 \\
\hline & \multicolumn{10}{|l|}{ BagPage $^{\circledR}$} \\
\hline & +80 & 74 & 663 & 106 & 58 & 8 & 183 & 1092 & 82 & 8.2 \\
\hline CCAP & Bead & & & & & & & & & \\
\hline \multirow[t]{3}{*}{$1119 / 32$} & beating & 0 & 782 & 26 & 21 & 0 & 92 & 921 & 100 & 9.5 \\
\hline & \multicolumn{10}{|l|}{ BagPage $^{\circledR}$} \\
\hline & +80 & 0 & 607 & 33 & 19 & 0 & 106 & 765 & 83 & 7.9 \\
\hline
\end{tabular}


Table 2. Qualitative assessment of the portable assay at Alexandrium spp. cell densities of 50,10 and 5 cells/L.

50 Cells $\quad 10$ Cells 5 Cells

Alexandrium Strain $(n=6) \quad$ Negative Positive Negative Positive Negative Positive

\begin{tabular}{lcccccc} 
Alexandrium tamarense 1119/20 & 6 & 0 & 6 & 0 & 4 & 2 \\
Alexandrium tamarense 1119/27 & 0 & 6 & 0 & 6 & 0 & 6 \\
Alexandrium tamarense 1119/32 & 0 & 6 & 0 & 6 & 0 & 6 \\
Alexandrium fundyense GTCA28 & 0 & 6 & 0 & 6 & 0 & 6 \\
Alexandrium fundyense F14 & 0 & 6 & 0 & 6 & 0 & 6 \\
\hline
\end{tabular}

Negative refers to concentrations $<20 \mathrm{pg} /$ cell, Positive refers to concentrations $>20 \mathrm{pg} / \mathrm{cell}$ 
Table 3. Performance of the portable assay for the qualitative determination of STX in Alexandrium spp. at 50 and 10 cells/L.

50 Cells

Alexandrium Strain

HPLC

Portable Assay

HPLC

10 Cells

$\begin{array}{ccc}\text { (STX pg/50 Negative/Positive } & \text { (STX pg/10 Negative/Positive } \\ \text { cells) } & \text { cells) }\end{array}$

Alexandrium tamarense

0

Negative

Negative

$1119 / 20$

Alexandrium tamarense

82

Positive

16

Positive

$1119 / 27$

Alexandrium tamarense

48

Positive

10

Positive

$1119 / 32$

Alexandrium fundyense GTCA28

76

93

Positive

$15 \quad$ Positive

Alexandrium fundyense

F14

Negative refers to concentrations $<20 \mathrm{pg} /$ cell, Positive refers to concentrations $>20 \mathrm{pg} / \mathrm{cell}$

\section{Development and validation of an ultrasensitive fluorescence planar waveguide} biosensor for the detection of paralytic shellfish toxins in marine algae

Julie P. Meneely ${ }^{a^{*}}$, Katrina Campbell ${ }^{a}$, Charles Greef ${ }^{b}$, Michael J Lochhead ${ }^{b}$, Christopher T Elliott ${ }^{a}$ 
${ }^{a}$ Institute of Agri-food and Land Use, School of Biological Sciences, Queen's University, Malone Road, Belfast, BT9 5BN, United Kingdom

${ }^{b}$ MBio Diagnostics Inc, Boulder, Colorado, 80301, USA 
SI Procedure: Assessment of the reproducibility of the printed waveguides.

The reproducibility of the printed waveguides was determined as follows. Under buffer conditions, two batches of waveguides were tested on four separate occasions over a period of several months $(n=16)$ for each calibration point whereas matrix calibration curves were repeated three times using three different batches over three days $(n=12)$. The fluorescence signal for each calibration solution was normalized by calculating the percentage of bound ligand (antibody) for each calibration point relative to the zero calibration fluorescence signal, the mean values plotted and the results indicate that the print procedure was both repeatable and reproducible for both buffer (Figure SI1) and matrix (Figure SI2). In addition, the results have been tabulated (buffer curves, Table SI1 and matrix curves Table SI2), highlighting the standard deviations and \%CVs for each. For pg levels of toxin, the CV values are acceptable and the highest $\mathrm{CV}$ values occur at the high concentrations, i.e. where the calibration curves flatten out and almost $100 \%$ inhibition is observed. Please note the buffer calibration curves were performed during the early assay development stages and the points used were different from the final assay. For buffer the calibration points used were $0,0.025,0.05$ and $0.25 \mathrm{ng} / \mathrm{ml}$ while for matrix they were changed to $0,0.02,0.04$ and $0.08 \mathrm{ng} / \mathrm{ml}$. 


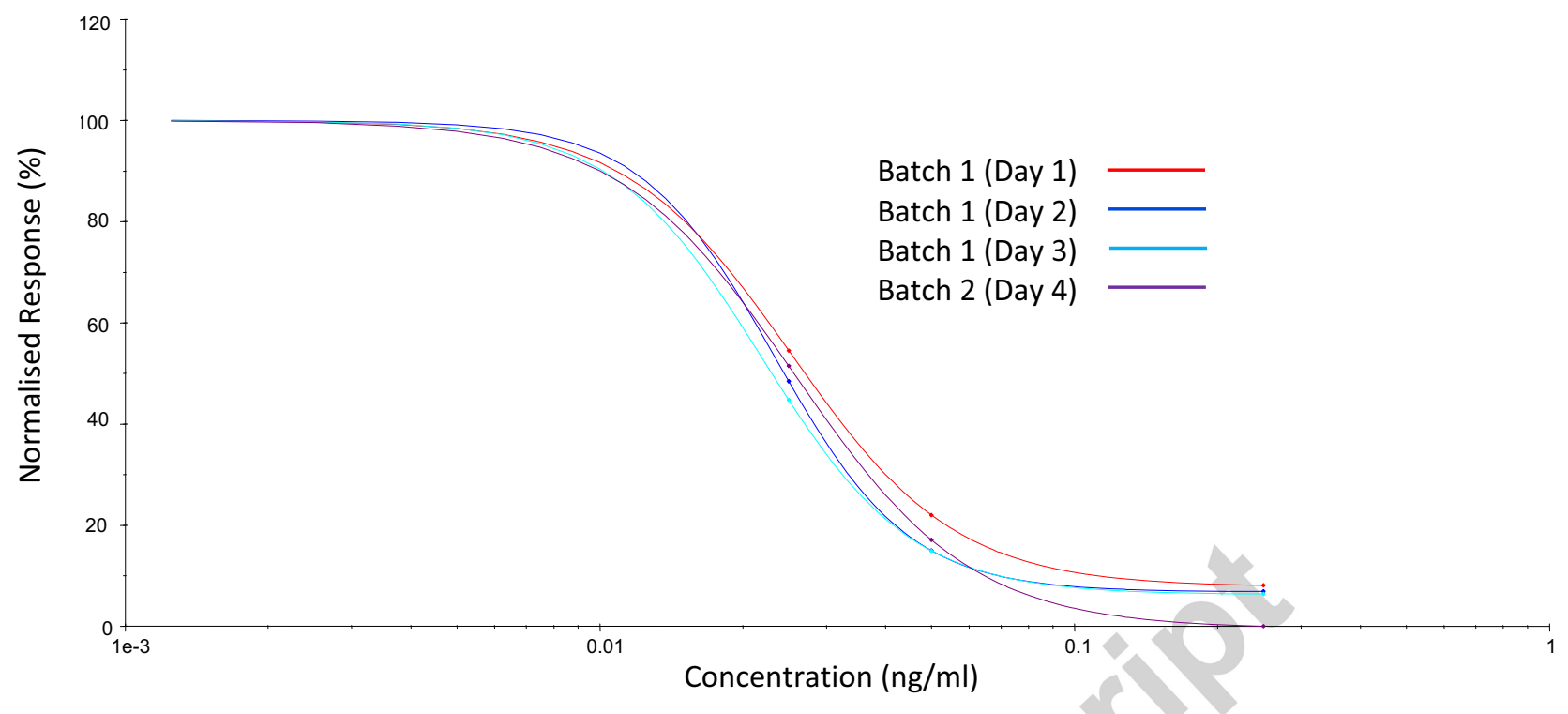

Fig SI1. Buffer calibration curves performed using 2 batches of printed microarrays over a period of several months (September to March).

*Colour reproduction on the Web. 


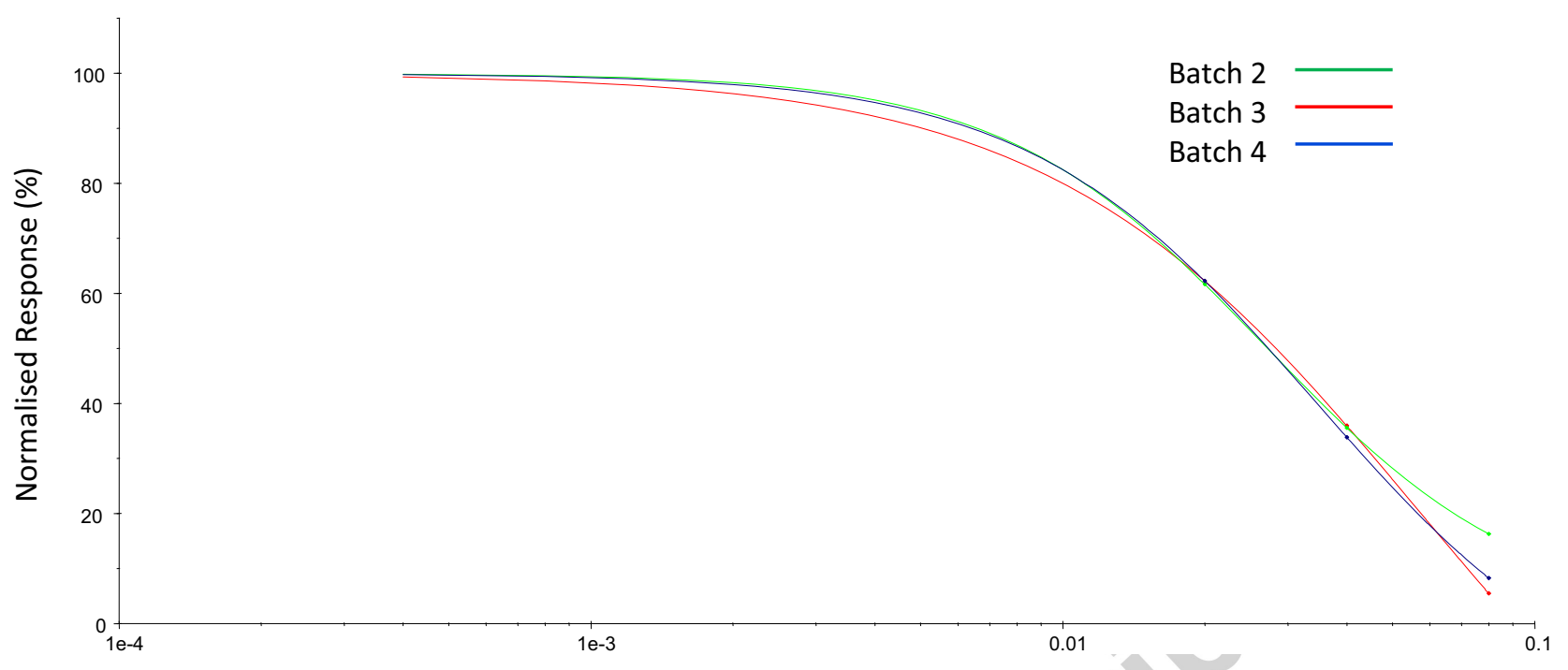

Fig SI2. Matrix calibration curves performed using 3 batches of printed microarrays over 3 different occasions.

*Colour reproduction on the Web. 
Table SI1. Assessment of waveguide reproducibility by comparing buffer calibration curves on 2 batches (4 occasions) over several months.

\begin{tabular}{|c|c|c|c|c|c|c|c|}
\hline Concentration & Day 1 & Day 2 & Day 3 & Day 4 & Mean & sd & CV \\
\hline \multirow[t]{3}{*}{ (ng/mL) } & Normalised & Normalised & Normalised & Normalised & & & $(\%)$ \\
\hline & Signal & Signal & Signal & Signal & & & \\
\hline & $(n=4)$ & $(n=4)$ & $(n=4)$ & $(n=4)$ & & & \\
\hline 0 & 100 & 100 & 100 & 100 & 100 & $n / a$ & $\mathrm{n} / \mathrm{a}$ \\
\hline 0.025 & 54.5 & 48.5 & 44.7 & 51.5 & 49.8 & 4.2 & 8.4 \\
\hline 0.05 & 22.0 & 15.0 & 15.0 & 17.1 & 17.3 & 3.3 & 19.3 \\
\hline 0.25 & 8.1 & 6.9 & 6.4 & 0 & 5.3 & 3.6 & 68.1 \\
\hline $\mathrm{IC}_{50}(\mathrm{ng} / \mathrm{mL})$ & 0.025 & 0.023 & 0.022 & 0.026 & & & \\
\hline
\end{tabular}


Table SI2. Assessment of waveguide reproducibility by comparing matrix calibration curves on 3 batches over 3 days.

\begin{tabular}{ccccccc}
\hline $\begin{array}{c}\text { Concentration } \\
(\mathrm{ng} / \mathrm{mL})\end{array}$ & Batch 2 & Batch 3 & Batch 4 & Mean & sd & CV (\%) \\
& $(n=4)$ & $(n=4)$ & $(n=4)$ & & & \\
\hline 0 & 100 & 100 & 100 & 100 & n/a & n/a \\
0.02 & 62.3 & 61.7 & 62.3 & 62.1 & 0.3 & 0.56 \\
0.04 & 36.0 & 35.6 & 33.9 & 35.2 & 1.1 & 3.2 \\
0.08 & 5.5 & 16.3 & 8.3 & 10.0 & 5.6 & 55.9 \\
$\mathrm{IC}_{50}(\mathrm{ng} / \mathrm{mL})$ & 0.026 & 0.022 & 0.025 & & & \\
\hline
\end{tabular}


a. Paralytic shellfish toxins can enter the food web risking human health.

b. Coastal monitoring of Alexandrium spp. can provide an early warning of risk.

c. A highly innovative sample preparation method was developed.

d. A sensitive rapid, portable assay was developed for paralytic shellfish toxins in seawater.

e. The test was proven to accurately detect toxin presence in algae an unprecedented cell density. 
Fig. 1.

\begin{tabular}{|c|c|c|c|c|c|c|c|c|c|c|c|c|c|}
\hline 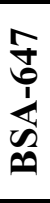 & 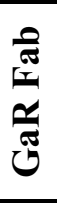 & 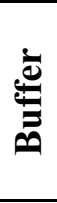 & 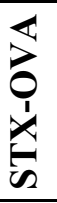 & \begin{tabular}{l}
\multicolumn{1}{c}{} \\
0 \\
1 \\
0 \\
ol \\
$z$
\end{tabular} & $\begin{array}{l}\sqrt{n} \\
0 \\
\frac{1}{b} \\
0\end{array}$ & $\begin{array}{l}4 \\
0 \\
1 \\
0 \\
1 \\
z\end{array}$ & 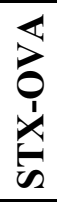 & \begin{tabular}{l}
\multicolumn{1}{c}{} \\
0 \\
1 \\
0 \\
ol \\
$z$
\end{tabular} & $\begin{array}{l}\sqrt{1} \\
0 \\
\frac{1}{x} \\
0\end{array}$ & $\begin{array}{l}1 \\
0 \\
0 \\
0 \\
0 \\
z \\
1\end{array}$ & 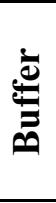 & 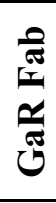 & 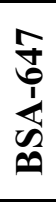 \\
\hline- & - & $\theta$ & § & \& & in & ถึ & $\stackrel{ }{=}$ & 으 & $\ddot{n}$ & $\ddot{n}$ & $\theta$ & - & $=$ \\
\hline 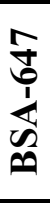 & 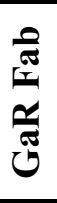 & $\stackrel{\bar{\varpi}}{\bar{E}}$ & 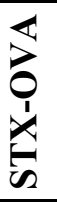 & $\begin{array}{l}4 \\
0 \\
0 \\
1 \\
0 \\
z \\
z\end{array}$ & 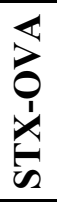 & $\begin{array}{l}4 \\
0 \\
0 \\
0 \\
1 \\
z\end{array}$ & 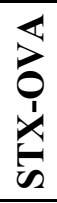 & $\begin{array}{l}4 \\
0 \\
0 \\
1 \\
0 \\
z \\
z\end{array}$ & 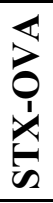 & $\begin{array}{l}4 \\
0 \\
0 \\
0 \\
0 \\
z \\
1\end{array}$ & 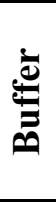 & 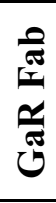 & $\begin{array}{l}\text { Jै } \\
\text { i } \\
\text { Dी }\end{array}$ \\
\hline- & - & $\theta$ & ๕̊ & 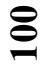 & in & ถึ & 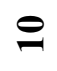 & 으 & ?ִ & $\stackrel{n}{n}$ & 0 & - & - \\
\hline
\end{tabular}

$\frac{A}{A}$

B.

O 0 - 
Fig. 2.

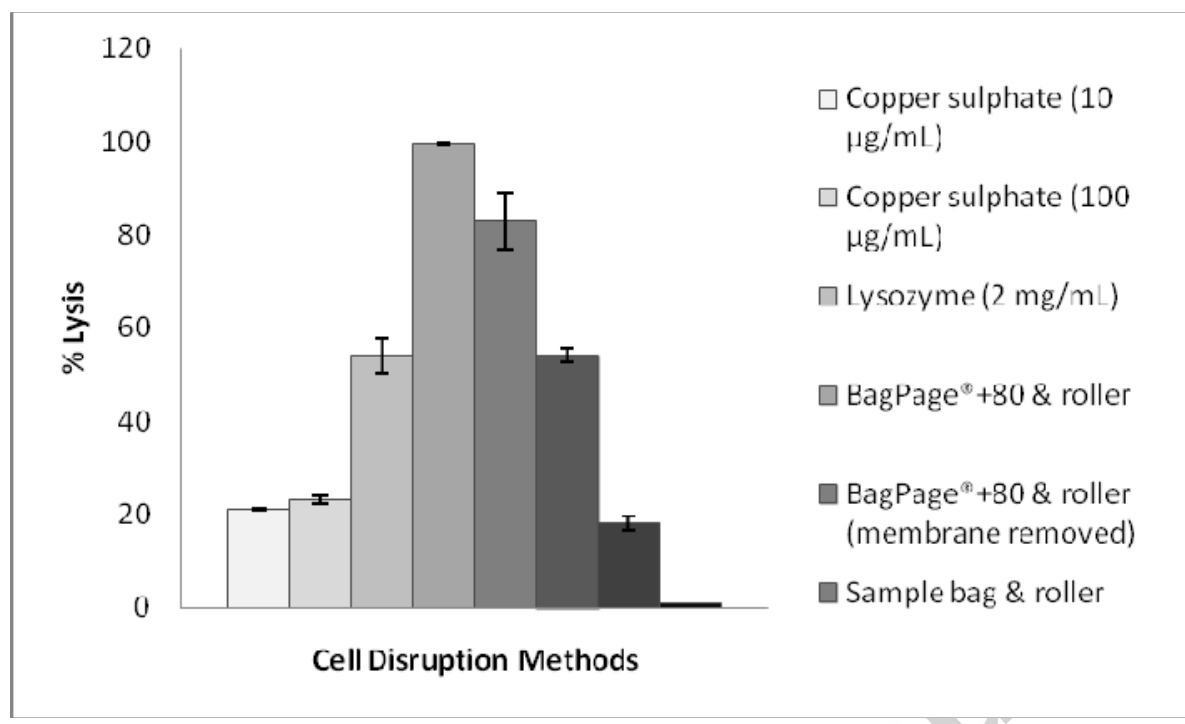


Fig. 3.

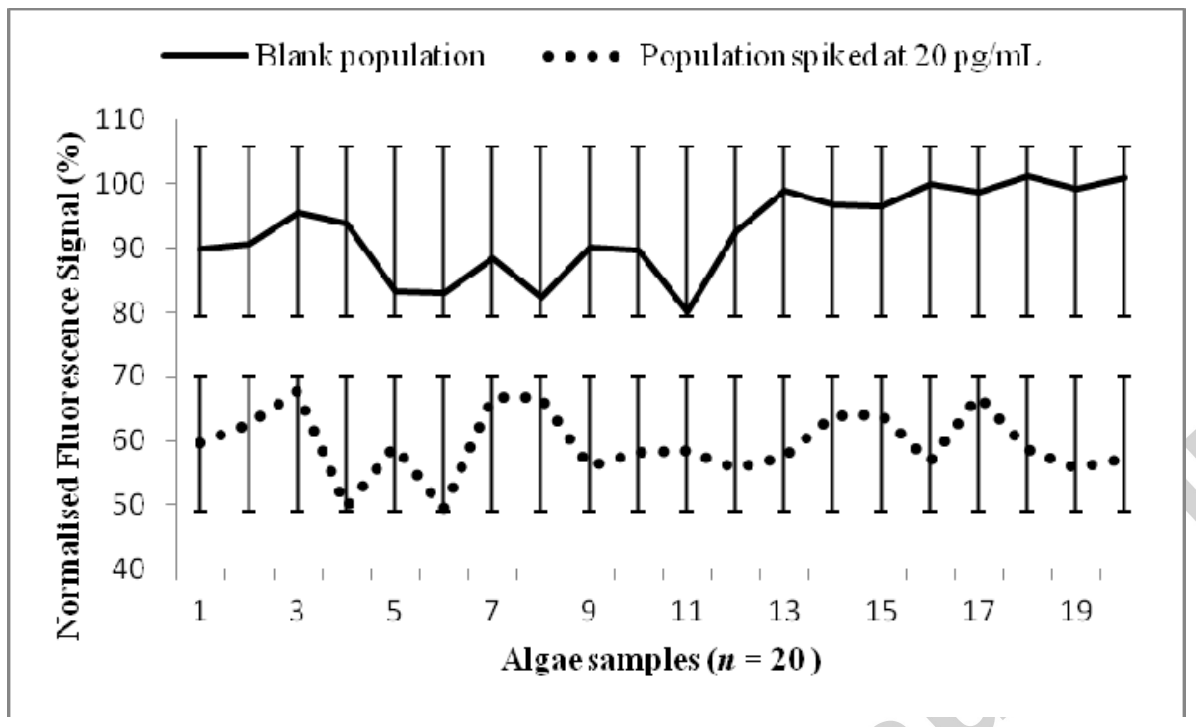

